\title{
Fotografia, Ciência e Educação
}

\author{
Antonio Carlos de Freitas \\ Formado em Física (UERJ); Mestre em Biociências Nucleares (UERJ) e Doutor em Ciências (UFRJ); Professor \\ Associado do Departamento de Biofísica e Biometria (DBB) do (IBRAG /UERJ); Coordenador do Núcleo de \\ Fotografia Científica Ambiental - BioCenas e Coordenador de Fotografia Científica da Associação dos \\ Fotógrafos de Natureza - AFNATURA $\left(^{*}\right)$ \\ $\triangle$ acafueri@gmail.com
}

Fotografar é muito mais que apertar o disparador da máquina. Esse é apenas um ato simples que finaliza um processo que começa com a nossa formação como cidadão; a forma de percebermos e interagirmos com o mundo que nos cerca. Fotografar é alinhar, através do visor da sua máquina, o sentimento, a emoção, a percepção, o intelecto e toda a nossa bagagem cultural e, em efêmeras frações de segundo, perpetuar o momento único, exclusivamente seu. Sim, só seu. Não existem duas fotos iguais, mesmo porque, não existem duas pessoas iguais; as percepções são únicas. A fotografia é uma forma de expressão do nosso estado de espírito, o nosso momento, por isso ela é única.

O fotógrafo engajado na elaboração desse momento único, não bate e nem tira a foto. Ele faz a foto. Ele pensa no que está fazendo antes de apertar o botão e só depois, materializa através desse ato, a foto que já havia sido feita na sua cabeça. Do ponto de vista filosófico, ele cria um resumo de uma realidade quadridimensional, que passará a ser observada em um plano bidimensional. Talvez seja esse o maior desafio do fotógrafo, representar no plano, o que vemos em profundidade. $O$ ato de fazer fotografia é, portanto, um compromisso.

A fotografia apresenta um amplo leque de aplicações, desde as formas mais livres a forma mais comprometida com a realidade, como por exemplo, a fotografia cientifica. Essa tem por objetivo ser o mais fiel possível ao tema fotografado, respeitando as cores, proporções, texturas, padrões e forma e tudo o mais que permita uma melhor análise das informações registradas.

A fotografia cientifica elaborada dentro de critérios técnicos e estéticos amplia a capacidade de observação do pesquisador, transcendendo ao registro visual, podendo, inclusive, ser utilizada como comprovação de um fato, contribuindo objetivamente no 
processo de educação, interpretação e análise de dados. Visto sob esse aspecto, a fotografia aplicada a ciência ambiental, desde os seus primórdios, tem como objetivo retratar a natureza da forma como ela nos é revelada. Tornou-se então, mais que um processo, um método científico que vem sendo amplamente empregado desde então.

É grande o número de cientistas que se utilizam da fotografia nos seus trabalhos de campo ou em laboratório, no entanto a qualidade das imagens não é proporcional à sua utilização. Apesar de tudo, ainda falta quebrar um paradigma antigo onde a fotografia é vista apenas como ilustração, como coadjuvante no processo científico.

Estamos caminhando, mas ainda é necessário implantar na área científica, a educação visual, desenvolvendo o olhar crítico e despertando o olhar fotográfico nos estudantes e cientistas que se utilizam da fotografia nos seus trabalhos acadêmicos e científicos. Existem vários cientistas que são fotógrafos que estão empenhados na luta por essa educação, na certeza de que a qualidade das imagens irá refletir, proporcionalmente, na qualidade dos seus trabalhos. De um provérbio chinês, uma imagem vale mais que mil palavras; imaginem então a abrangência e o alcance de uma boa imagem fotográfica contextualizada em um trabalho científico.

A fotografia como recurso visual e científico é a base para a mídia contemporânea, que nos inunda diariamente com milhares de imagens. Desta forma, precisa sem bem entendida e dominada no sentido da luz, já que fotografia é a escrita com a luz.

Nós do Núcleo de Fotografia Científica Ambiental - BioCenas, do Laboratório de Radioecologia e Mudanças Globais, do Departamento de Biofísica e Biometria no Instituto de Biologia Roberto Alcantara Gomes, da Universidade do Estado do Rio de Janeiro, estamos empenhados para reforçar e elevar cada vez mais, o status da fotografia como método científico. Já há algum tempo, o Núcleo BioCenas criou uma linha de pesquisa em Fotografia Científica Ambiental e vem desenvolvendo um relevante trabalho de registro fotográfico da biodiversidade dos biomas brasileiros, caracterização de ecossistemas e de divulgação científica.

Como elemento multiplicador, temos como objetivo também, a formação de novos fotógrafos na área ambiental. Promovemos isso em várias universidades brasileiras, capacitando-os a obter imagens fotográficas, tecnicamente e esteticamente elaboradas, que 
atendam a interesses didáticos e científicos. Acreditamos dessa forma, que estamos contribuindo para uma sociedade científica mais educada do ponto de vista visual.

$\left(^{*}\right)$ O autor trabalha com Fotografia Científica Ambiental há vários anos, tendo ministrado cursos, oficinas, exposições, saídas fotográficas e palestras na área, tendo sido agraciado com alguns prêmios até então. Ao longo dos anos vem ministrando a disciplina Fotografia Científica Ambiental para os Programas de Pós-graduação em: Biologia (UERJ), Ecologia (UERJ), Biologia Vegetal (UERJ), Ecologia (UFRJ), Medicina Veterinária (UFMT), Ecologia (UFMT), Biologia Animal (UFrRJ), Ecologia (UFSCAR), Ecologia UNESP de Botucatu, Ecologia UNESP de Rio Claro, Ecologia (UFJF), Biologia Animal UFrRJ entre outros. Nessa trajetória fotográfica elaborou um acervo com mais de 200 mil imagens digitais que retratam temas relacionados à Biodiversidade dos Biomas Brasileiros. Desenvolve suas atividades acadêmicas e científicas no Laboratório de Radioecologia e Mudanças Globais (LARAMG). Recentemente coordenou os projetos: "Criação do Núcleo de Fotografia Científica Ambiental para Estudos da Biodiversidade do Bioma Mata Atlântica no Estado do Rio de Janeiro" e "Implementação e Apoio Estrutural ao Núcleo de Fotografia Científica Ambiental - UERJ" com apoio da FAPERJ. Além disso, desenvolveu a homepage "Biodiversidade Para Todos" através do projeto "Biodiversidade Para Todos: Documentação e Informação da Diversidade do Bioma Mata Atlântica do Estado do Rio de Janeiro". Desenvolveu também, o projeto “Arte e Ciência das Formas e Padrões da Natureza", todos esses com o apoio da FAPERJ. 